\title{
Menopause and COVID19 severity: The missing link
}

COVID-19 pandemic has far-reaching consequences on people with comorbidities like Diabetes Mellitus(DM), asthma, cardiovascular disease, and cancer. ${ }^{1,2}$ What seems unusual is an isolated observation that emerged from several independent studies worldwide. Postmenopausal females seem to suffer from severe COVID symptoms. ${ }^{3}$ Few of them also show an extended COVID symptom, also "long COVID." ", Though the association appears strong, there are not enough credible studies to pin it down to the exact cause. We explored the possibility to see if postmenopausal females are at a higher risk for severe COVID and unravel this observation's molecular pathogenesis.

Research performed at King's College London found that as estrogen levels in females drop in pre-menopause and menopause, they become vulnerable to COVID19 infection, ${ }^{6}$ suggesting that high estrogen levels may have a protective effect against the severity of COVID-19. This concept originated from the immune-modulatory and immune suppressive role of estradiol., ${ }^{7,8}$ Although both male and female sex steroids act primarily on the reproductive tissues and modulate their functions, increasing evidence suggests that sex steroids can also work on non-reproductive tissues like the CNS, immune systems, cardiovascular and skeletal systems, etc. ${ }^{9,10}$ Further, estrogen has an enormous effect both on the innate (macrophages/monocytes, neutrophils, NK cells, complement systems, APC-like dendritic cells (DC)], as well as on the adaptive (B and $\mathrm{T}$ cells) immune system. ${ }^{11-13}$ There are reports that estrogen may exhibit a pro-inflammatory response, whereas testosterone counteracts it. ${ }^{14,15}$ This could possibly be through an estrogen-mediated production of inflammatory cytokines like IFN $\gamma$, interleukin (IL) 6, TNF $\alpha .^{16,17}$ However, estrogen also has a profound anti-inflammatory effect. ${ }^{18,19}$ We need to remember that many of these observations are context and cell-type-specific with a delicate balance between pro and anti-inflammatory responses. There needs a deeper understanding of the reproductive events in females. Perimenopause, menopause, and postmenopause define the end of a woman's reproductive years. These are the time when her monthly period stops. Whole perimenopause marks the beginning of this process, starting 8- 12 years before menopause. Menopause is the stage when her menstrual periods completely ceases for at least 12 months. Postmenopause is the stage after menopause that continues thereafter. Starting from perimenopause, menopause is marked by declining levels of estrogen((estrone
Access this article online

Website:

http://nepjol.info/index.php/AJMS

DOI: 10.3126/ajms.v12i9.38808

E-ISSN: 2091-0576

P-ISSN: 2467-9100

Copyright (c) 2021 Asian Journal of Medical Sciences

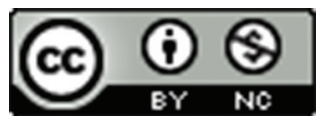

This work is licensed under a Creative Commons Attribution-NonCommercial 4.0 International License.

(E1), 17 $\beta$-estradiol (E2), estriol (E3)), and progesterone. However, there are complex hormonal and cytokine undercurrents to this rather simplistic profile. LH and FSH, however, seem to surge during this period. ${ }^{20,21}$ It currently not know what this LH/FSH surge means for the immune system. With the approach of menopause, there is the release of extracellular vesicles containing inflammasomes, which may be responsible for low-grade systemic inflammation. ${ }^{22,23}$ This cascade may build up significantly and contribute to a hyper-inflammatory environment.

According to a survey by Global Health 50/50, though an equal number of males and females were tested positive for COVID-19, the males were largely presented with severe symptoms, thereby implying that the female hormones may have a protective role in the pathophysiology of COVID-19. ${ }^{24}$ Further clinical studies performed on the females showed that pre-menopausal females have a relatively mild disease, while menopausal females had moderate to severe illness. ${ }^{25,26}$ The menopausal group also has significantly more requirements for oxygen, ventilation support, and progression-to-severe disease with a prolonged hospital stay and mortality. ${ }^{25}$

This is further reinforced by the fact that estradiol modulates the immune cells, which could play an essential role in explaining why a lower incidence of COVID-19 is observed among women than in men. Even been a nuclear hormone, estrogen has cytoplasmic targets. The cytoplasmic activity 
of estrogen-activated ER $\alpha$ leads to PI3K induction. ${ }^{26}$ This, in turn, prevents the nuclear shuttling and transport of NF-kB, resulting in reduced inflammation. ${ }^{27}$ The estrogen axis for inflammation is enormously complex, riddled by the different receptor types usage and post-receptor events. The presence of estrogen receptors (ESR), ER $\alpha$ and ER $\beta$, is of prime importance since the net outcome depends on ER subtypes in use. ${ }^{28}$ It seems that a preferential engagement of ERbeta promotes inflammation while ERalpha dampens it. ${ }^{29}$ It was further demonstrated that hypoxia, associated with inflammatory conditions, could also downregulate the expression of ERo, tipping the balance in favor of inflammation. ${ }^{29,30}$ Then there are interferon genes that cross talks with (Estrogen receptor) ESR signaling. ${ }^{31,32}$ Estrogen can also polarize toward a TH2 response eliciting a protective humoral response $e^{33}$ in addition to its capacity for activation of NK cells. ${ }^{34-36}$ Further, a wide variety of immunemodulatory roles is under estrogenic control. This involves the antigen-presenting dendritic cells, $\mathrm{CD} 4+$ and $\mathrm{CD} 8+\mathrm{T}$ cell populations..$^{37,38}$ Other than estrogen, progesterone also has a profound influence on the immune system. ${ }^{39,40}$ Progesterone was found to have an antiviral effect against SARS-CoV-2 in vitro. ${ }^{41,42}$ Mature $\mathrm{NK} \mathrm{CD} 56^{\mathrm{dim}} \mathrm{CD} 16^{+} \mathrm{KIR}^{+}$cells overexpress the progesterone receptor and thus are hormone-sensitive. ${ }^{43}$ Though there are conflicting reports regarding the association of disease severity and mortality with estrogen levels, it is plausible that drastic alteration of these hormones at menopause could perturb the delicate balance creating an environment that enhances the immune response fueling the cytokine storm, the hallmark for COVID complications. Further research in this area is needed to decipher the intricate molecular details of this process for future risk mitigation and disease management.

\section{Ruby Dhar ${ }^{1}$, Arun Kumar ${ }^{2}$, Subhradip Karmakar ${ }^{3}$}

${ }^{1}$ Scientist, Room No-3020 Department of Biochemistry, All India Institute of Medical Sciences, New Delhi, India, ${ }^{2}$ Professor and Head, Department of Biochemistry, Jagannath Gupta Institute of Medical Sciences and Hospital, Budge Budge, Kolkata, India, ${ }^{3}$ Associate-Professor, Room No-3020, Department of Biochemistry, All India Institute of Medical Sciences, New Delhi, India

Address for Correspondence: Dr. Arun Kumar, Professor and Head, Department of Biochemistry, Jagannath Gupta Institute of Medical Sciences and Hospital, Budge Budge, Kolkata, India. Mobile: +91-7584089886.

E-mail: arun732003@gmail.com

Dr. Subhradip Karmakar, Additional Professor, Room No-3020, Department of Biochemistry, All India Institute of Medical Sciences, New Delhi, India. Mobile: +91-9999612564. E-mail: subhradipaiims@gmail.com

\section{REFERENCES}

1. Sanyaolu A, Okorie C, Marinkovic A, Patidar R, Younis K, Desai $P$, et al. Comorbidity and its Impact on Patients with COVID-19. SN Compr Clin Med. 2020;1-8.

https://doi.org/10.1007/s42399-020-00363-4

2. Ng WH, Tipih T, Makoah NA, Vermeulen JG, Goedhals D, Sempa JB, et al. Comorbidities in SARS-CoV-2 Patients: A Systematic Review and Meta-Analysis. mBio. 2021;12(1): e03647-20.

https://doi.org/10.1128/mBio.03647-20

3. Seeland U, Coluzzi F, Simmaco M, Mura C, Bourne PE, Heiland $M$, et al. Evidence for treatment with estradiol for women with SARS-CoV-2 infection. BMC Med. 2020;18(1):369.

https://doi.org/10.1186/s12916-020-01851-z

4. Mendelson M, Nel J, Blumberg L, Madhi SA, Dryden M, Stevens W, et al. Long-COVID: An evolving problem with an extensive impact. S Afr Med J. 2020;111(1):10-12.

https://doi.org/10.7196/SAMJ.2020.v111i11.15433

5. Mahase E. Covid-19: What do we know about "long covid"? BMJ. 2020;370:m2815.

https://doi.org/10.1136/bmj.m2815

6. Post-menopausal women at higher risk of developing severe COVID-19, study finds.

https://www.kcl.ac.uk/news/post-menopausal-women-higherrisk-developing-severe-covid-19

7. Huang H, Zhou J, Chen H, Li J, Zhang C, Jiang X, et al. The immunomodulatory effects of endocrine therapy in breast cancer. J Exp Clin Cancer Res. 2021;40(1):19.

https://doi.org/10.1186/s13046-020-01788-4

8. Segner $\mathrm{H}$, Verburg-van Kemenade BML and Chadzinska M. The immunomodulatory role of the hypothalamus-pituitary-gonad axis: Proximate mechanism for reproduction-immune tradeoffs? Dev Comp Immunol. 2017; 66:43-60.

https://doi.org/10.1016/j.dci.2016.07.004

9. Fu XD and Simoncini T. Non-genomic sex steroid actions in the vascular system. Semin Reprod Med. 2007;25(3):178-86. https://doi.org/10.1055/s-2007-973430

10. Kumar A, Banerjee A, Singh D, Thakur G, Kasarpalkar N, Gavali S, et al. Estradiol: A Steroid with Multiple Facets. Horm Metab Res. 2018;50(5):359-374.

https://doi.org/10.1055/s-0044-100920

11. Moulton VR. Sex Hormones in Acquired Immunity and Autoimmune Disease. Front Immunol. 2018; 9:2279. https://doi.org/10.3389/fimmu.2018.02279

12. Trenti A, Tedesco S, Boscaro C, Trevisi L, Bolego C and Cignarella A. Estrogen, Angiogenesis, Immunity and Cell Metabolism: Solving the Puzzle. Int J Mol Sci. 2018;19(3):859. https://doi.org/10.3390/ijms19030859

13. Kovats $\mathrm{S}$. Estrogen receptors regulate innate immune cells and signaling pathways. Cell Immunol. 2015;294(2):63-69. https://doi.org/10.1016/j.cellimm.2015.01.018

14. Patel S, Homaei $A$, Raju $A B$ and Meher BR. Estrogen: The necessary evil for human health, and ways to tame it. Biomed Pharmacother. 2018; 102:403-411.

https://doi.org/10.1016/j.biopha.2018.03.078

15. Kassi E, Spilioti E, Nasiri-Ansari N, Adamopoulos C, Moutsatsou P, Papapanagiotou A, et al. Vascular Inflammation and Atherosclerosis: The Role of Estrogen Receptors. Curr Med Chem. 2015;22(22):2651-2665.

https://doi.org/10.2174/0929867322666150608093607

16. Merrheim J, Villegas J, Van Wassenhove J, Khansa R, BerrihAknin S, le Panse R, et al. Estrogen, estrogen-like molecules and autoimmune diseases. Autoimmun Rev. 2020;19(3):102468. https://doi.org/10.1016/j.autrev.2020.102468

17. Hao S, Li P, Zhao J, Hu Y and Hou Y. 17ß-Estradiol Suppresses Cytotoxicity and Proliferative Capacity of Murine Splenic NK1.1+ Cells. Cell Mol Immunol. 2008; 5: 357-364. https://doi.org/10.1038/cmi.2008.44 
18. Vegeto $\mathrm{E}$, Benedusi $\mathrm{V}$ and Maggi $\mathrm{A}$. Estrogen anti-inflammatory activity in brain: a therapeutic opportunity for menopause and neurodegenerative diseases. Front Neuroendocrinol. 2008;29(4):507-519.

https://doi.org/10.1016/j.yfrne.2008.04.001

19. Villa A, Rizzi N, Vegeto E, Ciana $P$ and Maggi A. Estrogen accelerates the resolution of inflammation in macrophagic cells. Sci Rep. 2015; 5: 15224

https://doi.org/10.1038/srep15224

20. Weiss G, Skurnick JH, Goldsmith LT, Santoro NF and Park SJ. Menopause and Hypothalamic-Pituitary Sensitivity to Estrogen. JAMA. 2004;292(24):2991-2996.

https://doi.org/10.1001/jama.292.24.2991

21. Sherman BM, West JH and Korenman SG. The menopausal transition: analysis of $\mathrm{LH}, \mathrm{FSH}$, estradiol, and progesterone concentrations during menstrual cycles of older women. J Clin Endocrinol Metab. 1976;42(4):629-636. https://doi.org/10.1210/jcem-42-4-629

22. Raval AP, Martinez CC, Mejias NH and de Rivero Vaccari JP. Sexual dimorphism in inflammasome-containing extracellular vesicles and the regulation of innate immunity in the brain of reproductive senescent females. Neurochem Int. 2019; 127:29-37. https://doi.org/10.1016/j.neuint.2018.11.018

23. $\mathrm{Xu} Y$, Sheng $\mathrm{H}$, Bao $\mathrm{Q}$, Wang $\mathrm{Y}$, Lu $\mathrm{J}$ and Ni $\mathrm{X}$. NLRP3 inflammasome activation mediates estrogen deficiencyinduced depression- and anxiety-like behavior and hippocampal inflammation in mice. Brain Behav Immun. 2016; 56:175-186. https://doi.org/10.1016/j.bbi.2016.02.022

24. The sex gender and COVID19 project. https://globalhealth5050.org/the-sex-gender-and-covid-19-project/

25. Mishra N, Sharma R, Mishra P, Singh M, Seth S, Deori T, et al. COVID-19 and Menstrual Status: Is Menopause an Independent Risk Factor for SARS Cov-2? J Midlife Health. 2020;11(4):240-249. https://doi.org/10.4103/jmh.JMH_288_20

26. Calls to investigate possible link between menopause and Covid risk

https://www.theguardian.com/world/2020/dec/04/callsinvestigate-possible-link-menopause-covid-risk

27. Xing D, Oparil S, Yu H, Gong K, Feng W, Black J, et al. Estrogen modulates NFKB signaling by enhancing $I \kappa B \alpha$ levels and blocking p65 binding at the promoters of inflammatory genes via estrogen receptor- $\beta$. PLoS One. 2012;7(6): e36890.

https://doi.org/10.1371/journal.pone.0036890

28. Paterni I, Granchi C, Katzenellenbogen JA and Minutolo F. Estrogen receptors alpha $(E R \alpha)$ and beta $(E R \beta)$ : subtypeselective ligands and clinical potential. Steroids. 2014; 90:13-29. https://doi.org/10.1016/j.steroids.2014.06.012

29. Heldring N, Pike A, Andersson S, Matthews J, Cheng G, Hartman J, et al. Estrogen receptors: how do they signal and what are their targets. Physiol Rev. 2007;87(3):905-931. https://doi.org/10.1152/physrev.00026.2006

30. Jia M, Dahlman-Wright K and Gustafsson JÅ. Estrogen receptor alpha and beta in health and disease. Best Pract Res Clin Endocrinol Metab. 2015;29(4):557-568.

https://doi.org/10.1016/j.beem.2015.04.008

Author's Contribution:

All authors contributed equally towards scripting of this editorial.

Orcid ID:

Dr. Ruby Dhar- (D) https://orcid.org/0000-0003-3600-6554

Dr. Arun Kumar- (i) https://orcid.org/0000-0002-8800-0296

Dr. Subhradip Karmakar- (1) https://orcid.org/0000-0002-4757-8729

Source of Funding: None, Conflict of Interest: None.
31. Fox HS, Bond BL and Parslow TG. Estrogen regulates the IFNgamma promoter. J Immunol. 1991;146(12):4362-4367.

32. Dragin N, Nancy P, Villegas J, Roussin R, Panse RL and BerrihAknin S. Balance between Estrogens and Proinflammatory Cytokines Regulates Chemokine Production Involved in Thymic Germinal Center Formation. Sci Rep. 2017; 7: 7970. https://doi.org/10.1038/s41598-017-08631-5

33. Javadian A, Salehi E, Bidad K, Sahraian MA and Izad M. Effect of estrogen on Th1, Th2 and Th17 cytokines production by proteolipid protein and PHA activated peripheral blood mononuclear cells isolated from multiple sclerosis patients. Arch Med Res. 2014;45(2):177-182.

https://doi.org/10.1016/j.arcmed.2014.01.002

34. Nilsson $\mathrm{N}$ and Carlsten $\mathrm{H}$. Estrogen induces suppression of natural killer cell cytotoxicity and augmentation of polyclonal B cell activation. Cell Immunol. 1994;158(1):131-139. https://doi.org/10.1006/cimm.1994.1262

35. Curran EM, Berghaus LJ, Vernetti NJ, Saporita AJ, Lubahn DB and Estes DM. Natural killer cells express estrogen receptoralpha and estrogen receptor-beta and can respond to estrogen via a non-estrogen receptor-alpha-mediated pathway. Cell Immunol. 2001;214(1):12-20.

https://doi.org/10.1006/cimm.2002.1886

36. AJ, Lubahn DB and Estes DM. Natural killer cells express estrogen receptor-alpha and estrogen receptor-beta and can respond to estrogen via a non-estrogen receptor-alpha-mediated pathway. Cell Immunol. 2001;214(1):12-20. https://doi.org/10.1006/cimm.2002.1886

37. Kovats $\mathrm{S}$. Estrogen receptors regulate innate immune cells and signaling pathways. Cell Immunol. 2015;294(2):63-69. https://doi.org/10.1016/j.cellimm.2015.01.018

38. Laffont $S$, Seillet $C$ and Guéry JC. Estrogen Receptor-Dependent Regulation of Dendritic Cell Development and Function. Front Immunol. 2017; 8:108. https://doi.org/10.3389/fimmu.2017.00108

39. Robinson DP and Klein SL. Pregnancy and pregnancyassociated hormones alter immune responses and disease pathogenesis. Horm Behav. 2012;62(3):263-271. https://doi.org/10.1016/j.yhbeh.2012.02.023

40. Shah NM, Imami N and Johnson MR. Progesterone Modulation of Pregnancy-Related Immune Responses. Front Immunol. 2018; 9:1293. https://doi.org/10.3389/fimmu.2018.01293

41. Study: Progesterone Therapy May Improve COVID-19 Outcomes for Men.

https://www.cedars-sinai.org/newsroom/study-progesteronetherapy-might-improve-covid-19-outcomes-for-men/

42. Progesterone therapy may improve COVID-19 outcomes for men, study finds.

https://www.sciencedaily.com/releases/2021/03/210318141628.htm

43. Arruvito L, Giulianelli S, Flores AC, Paladino N, Barboza M, Lanari $C$, et al. NK cells expressing a progesterone receptor are susceptible to progesterone-induced apoptosis. J Immunol. 2008;180(8):5746-5753.

https://doi.org/10.4049/jimmunol.180.8.5746 